\title{
Inhibitor of Growth Protein 2
}

National Cancer Institute

\section{Source}

National Cancer Institute. Inhibitor of Growth Protein 2. NCI Thesaurus. Code C77207.

Inhibitor of growth protein 2 (280 aa, $\sim 33 \mathrm{kDa}$ ) is encoded by the human ING2 gene. This protein plays a role in apoptosis through the modulation of the acetylation of tumor protein 53. 